\title{
Reorganization of the Genus Erythromicrobium: Description of "Erythromicrobium sibiricum" as Sandaracinobacter sibiricus gen. nov., sp. nov., and of "Erythromicrobium ursincola" as Erythromonas ursincola gen. nov., sp. nov.
}

\author{
V. YURKOV,${ }^{1 *}$ E. STACKEBRANDT, ${ }^{2}$ O. BUSS,${ }^{2}$ A. VERMEGLIO,${ }^{3}$ V. GORLENKO, ${ }^{4}$ AND J. T. BEATTY ${ }^{1}$ \\ Department of Microbiology and Immunology, University of British Columbia, Vancouver, British Columbia, \\ Canada V6T 1Z3'; DSMZ_German Collection of Microorganisms and Cell Cultures, D-38124, \\ Braunschweig, Germany'; DEVM, LBC, CEA Cadarache, 13108 St. Paul lez Durance, \\ France $^{3}$; and Institute of Microbiology, Academy of Sciences, Moscow, Russia ${ }^{4}$
}

\begin{abstract}
The results of investigations on the morphology, physiology, pigment composition, light-harvesting antenna and reaction center organization, and electron carriers of five Erythromicrobium representatives, and on phylogenetic relations among them, are summarized. On the basis of clear phenotypic differences and distinct phylogenetic positions shown by $16 \mathrm{~S}$ ribosomal DNA analysis, the tentative species "Erythromicrobium sibiricum" and "Erythromicrobium ursincola" are formally described as the type species of two new genera: Sandaracinobacter sibiricus gen. nov., sp. nov., and Erythromonas ursincola gen. nov., sp. nov., respectively. The genus Erythromicrobium is at present composed of the type species, $E$. ramosum, and two species, "E. hydrolyticum" and "E. ezovicum," whose nomenclature is yet to be validated. All species studied group within the $\alpha-4$ subclass of Proteobacteria.
\end{abstract}

Obligately aerobic bacteriochlorophyll $a(\mathrm{Bchl} a)$-containing bacteria have been found at several geographical places in different ecological niches $(8,23,24,35,36)$. They are represented by marine species of the genera Erythrobacter and Roseobacter $(21,22)$ and by freshwater species of the genera Erythromicrobium, Roseococcus $(32,36,37,40)$, and Porphyrobacter (8). The main features of this group are inability to grow photosynthetically under anaerobic conditions despite the presence of $\mathrm{Bchl} a$, low levels of photosynthetic units in cells, and strong inhibition by light of Bchl $a$ synthesis $(12,34)$.

The first representative of freshwater obligately aerobic Bchl $a$-containing bacteria, isolated from thin microbial mats formed near underwater hydrothermal vents of the Bol'shoi River (Baykal Lake region) in Russia, was ascribed to the marine genus Erythrobacter (22) and named "Erythrobacter sibiricus" (31). This assignment was made on the basis of Bchl $a$ production connected with strict aerobiosis. However, since that time "E. sibiricus" was reclassified into the genus Erythromicrobium, a new genus for freshwater obligately aerobic anoxygenic photosynthetic bacteria $(30,36)$.

Based on phenotypic similarities, the five recently isolated species "E. sibiricum," "E. ursincola," "E. ezovicum," "E. hydrolyticum," and $E$. ramosum were included in the same genus, Erythromicrobium (36). However, DNA-DNA hybridization data showed that DNA from the species "E. sibiricum" and "E. ursincola" had very low homology (11 to 27\%) with the other three species of this genus (36). It was proposed that additional physiological, biochemical, and ribosomal DNA (rDNA) sequence analyses might demonstrate clear differences between " $E$. sibiricum" and " $E$. ursincola," on the one hand, and the other orange freshwater bacteria, on the other (36). In agreement with this proposal, an analysis of 5S rRNA sequences confirmed the genetic heterogeneity of the genus Erythromicrobium (28).

* Corresponding author. Phone: (604) 822-9307. Fax: (604) 8226041. E-mail: yurkov@unixg.ubc.ca.
In this paper we exclude "E. sibiricum" and "E. ursincola" from the genus Erythromicrobium and describe them as the members of two new genera, Sandaracinobacter and Erythromonas, respectively, on the basis of results of morphological, biochemical, physiological, molecular biological, and phylogenetic analyses.

\section{MATERIALS AND METHODS}

Bacterial strains. The following species were investigated: the type species of genus Erythromicrobium, E. ramosum $\mathrm{E} 5$, "E. sibiricum" RB16-17, "E. ursincola" KR-99, "E. ezovicum" E-1, and "E. hydrolyticum" E4(1) $(31,33,36,37,40)$ (from the personal collection of V. Yurkov).

Culture media. The strains were cultivated in Erlenmeyer flasks aerobically in the dark at $30^{\circ} \mathrm{C}$ and at $\mathrm{pH} 7.6$ to 7.8 in a medium containing the following (in grams per liter): yeast extract, 1.0; Bacto Peptone, 1.0; sodium acetate, $1.0 ; \mathrm{KCl}$, $0.3 ; \mathrm{MgSO}_{4} \cdot 7 \mathrm{H}_{2} \mathrm{O}, 0.5 ; \mathrm{CaCl}_{2} \cdot 2 \mathrm{H}_{2} \mathrm{O}, 0.05 ; \mathrm{NH}_{4} \mathrm{Cl}, 0.3 ; \mathrm{K}_{2} \mathrm{HPO}_{4}, 0.3$. The medium was supplemented with $20 \mu \mathrm{g}$ of vitamin $\mathrm{B}_{12} /$ liter and $1.0 \mathrm{ml}$ of a trace element solution/liter (4)

Isolation of soluble cyt's, membranes, and pigment-protein complexes. Cells were harvested by centrifugation at the end of the exponential-growth phase,

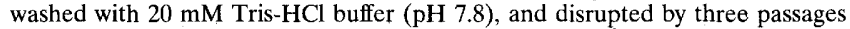
through a French pressure cell operated at $16,000 \mathrm{lb} / \mathrm{in}^{2}$. Unbroken cells and large debris were removed by centrifugation at $12,000 \times g$ for $15 \mathrm{~min}$. The supernatant fluid was centrifuged at $150,000 \times g$ for $3 \mathrm{~h}$ to separate soluble proteins from membranes, which were individually assayed for cytochrome (cyt) $c$ content.

The method of fractionation of cell membranes and isolation of light-harvesting complex II (LHII) and reaction center (RC)-LHI complexes has been described elsewhere $(38,39)$.

Analytical methods. Membranes were analyzed for the presence of cyt $c$ and molecular weights (MW) by sodium dodecyl sulfate-polyacrylamide gel electrophoresis (SDS-PAGE) (11.5 to $16.5 \%$ linear gradient of acrylamide) and were stained with $3,3^{\prime}, 5,5^{\prime}$-tetramethylbenzidine (TMBZ) in the presence of hydrogen peroxide as described elsewhere (27)

The presence of Bchl and carotenoids in Blastomonas natatoria was evaluated by using acetone-methanol (7:2) extracts.

Spectroscopic procedures. Absorption spectra were recorded at room temperature with a Hitachi U-2000 spectrophotometer.

Electron microscopy. Cells from the mid-logarithmic-growth phase were fixed in filtered $2.5 \%$ glutaraldehyde in $0.1 \mathrm{M}$ sodium cacodylate buffer containing 5.0 $\mathrm{mM} \mathrm{CaCl} 2\left(\mathrm{pH} \mathrm{7.0)}\right.$ at $4^{\circ} \mathrm{C}$ for $2 \mathrm{~h}$, embedded in $4.0 \%$ agarose, and cut into cubes. Agarose cubes were progressively dehydrated in ethanol solutions from 10 to $96 \%$ and then in propylene oxide. Dehydrated cubes were embedded in LR white resin (London Resin Company, Ltd., London, England) and polymerized at $70^{\circ} \mathrm{C}$ for $9 \mathrm{~h}$. Ultrathin sections were stained with uranyl acetate and lead 
TABLE 1. Major characteristics of Erythromicrobium representatives ${ }^{a}$

\begin{tabular}{|c|c|c|c|c|c|}
\hline Characteristic & "E. sibiricum" & "E. ursincola" & E. ramosum & "E. ezovicum" & "E. hydrolyticum" \\
\hline Cell shape and size $(\mu \mathrm{m})$ & $\begin{array}{l}\text { Thin, long bacilli; } \\
0.3-0.5 \times 1.5-2.5\end{array}$ & $\begin{array}{l}\text { Ovoid; } 0.8-1.0 \times \\
1.3-2.6\end{array}$ & $\begin{array}{l}\text { Bacilli, branched; } \\
0.7-1.0 \times 1.6-2.5\end{array}$ & $\begin{array}{l}\text { Long bacilli; } \\
\quad 0.6-0.8 \times 2.7-2.8\end{array}$ & $\begin{array}{l}\text { Bacilli, branched; } \\
0.7-1.1 \times 1.8-2.5\end{array}$ \\
\hline Color & Yellow-orange & Orange-brown & Red-orange & Red-orange & Red-orange \\
\hline Major carotenoid in vivo peaks (nm) & $424,450,474$ & $430,458,485$ & 466,478 & 466,478 & 466,478 \\
\hline \multicolumn{6}{|l|}{ Utilization of: } \\
\hline Glucose & + & + & + & + & + \\
\hline Maltose & + & + & + & + & + \\
\hline Acetate & + & + & + & + & + \\
\hline Pyruvate & + & + & + & - & + \\
\hline Butyrate & + & + & + & + & - \\
\hline Malate & - & + & + & + & + \\
\hline Citrate & - & + & + & + & + \\
\hline Succinate & - & + & + & + & + \\
\hline Lactate & - & + & + & + & + \\
\hline Ethanol & - & - & + & + & + \\
\hline Methanol & - & - & - & - & - \\
\hline \multicolumn{6}{|l|}{ Antibiotic sensitivity to: } \\
\hline Penicillin & - & - & - & - & ND \\
\hline Tetracycline & - & + & - & - & ND \\
\hline Streptomycin & + & - & + & + & ND \\
\hline Polymyxin B & - & + & - & - & ND \\
\hline Bacitracin & + & - & + & + & ND \\
\hline Kanamycin & + & - & + & + & ND \\
\hline Chloramphenicol & + & + & + & + & ND \\
\hline DNA G $+\mathrm{C}$ content $(\mathrm{mol} \%)$ & 68.5 & 65.4 & 64.2 & 62.5 & 65.2 \\
\hline
\end{tabular}

\footnotetext{
${ }^{a}$ This table is created from the data presented in references $31,33,36,37$, and $40 .+$, substrate is utilized or antibiotic sensitivity. - , substrate is not utilized or
} antibiotic resistance. ND, not determined.

citrate and were examined with a JEOL transmission electron microscope, model 12000 , Ex2, as previously described (42).

$16 S$ rDNA analysis. Isolation of genomic DNA, PCR-mediated amplification of $16 \mathrm{~S}$ rDNA, and purification of PCR products were performed as previously described (19). Sequences of purified PCR products were determined by using a Taq DyeDeoxy terminator cycle sequencing method (Applied Biosystems Co., Foster City, Calif.) as described in the manufacturer's protocol. The $16 \mathrm{~S}$ rDNA sequences obtained were aligned manually with sequences of members of the $\alpha-4$ subclass of the Proteobacteria.

Pairwise evolutionary distances were computed by using the correction of Jukes and Cantor (15). The distance matrix method (3) and the neighbor-joining method (20) were used to construct phylogenetic trees from the distance matrices. Bootstrap values calculated for 300 trees were generated by using the algorithms (7).

Nucleotide sequence accession numbers. The 16S rDNA sequences determined in this study have been deposited in the EMBL database (Cambridge, United Kingdom) under accession no. Y10678 for Sandaracinobacter sibiricus RB16-17 $7^{\mathrm{T}}$ and Y10677 for Erythromonas ursincola KR99 ${ }^{\mathrm{T}}$. Because of the many ambiguous nucleotides in the $16 \mathrm{~S}$ rRNA sequence of $B$. natatoria available in the EMBL data bank under accession no. X73043, a new sequence was obtained from $B$. natatoria DSM 3183 and submitted to the EMBL data bank under accession no. Y13774. The reference sequences were obtained from the European Molecular Biology Laboratory or from the Ribosomal Database Project (16). The nucleotide sequence accession numbers for the reference strains are given as follows (for those described previously, reference numbers are given): Erythrobacter longus ATCC 33941 ${ }^{\mathrm{T}}$, M59062; Erythromicrobium ramosum DSM $8510^{\mathrm{T}}, \mathrm{X} 72909$; Rhodobacter capsulatus $\mathrm{B} 10$, reference 16; Rhodopila globiformis DSM $161^{\mathrm{T}}$, reference 16 ; Roseobacter denitrificans Och114 ${ }^{\mathrm{T}}$, reference 16 ; Roseococcus thiosulfatophilus DSM 8511 ${ }^{\mathrm{T}}$, X72908; Sphingomonas adhaesiva JCM $7370^{\mathrm{T}}, \mathrm{X72720}$; Sphingomonas capsulata ATCC $14666^{\mathrm{T}}, 59296$; Sphingomonas rosa IFO 15208 ${ }^{\mathrm{T}}, \mathrm{D} 13945$; Sphingomonas macrogoltabidus IFO $15033^{\mathrm{T}}, \mathrm{D} 13723$; Sphingomonas terrae IFO 15098 ${ }^{\mathrm{T}}$, D13727; Sphingomonas yanoikuyae IFO $15102^{\mathrm{T}}$, X72725; Sphingomonas subarctica HAMBI 2110 ${ }^{\mathrm{T}}$, X94102; Sphingomonas paucimobilis DSM $1098^{\mathrm{T}}$, X72722; Sphingomonas paucimobilis DSM 7562, X94100; Sphingomonas chlorophenolica ATCC $33790^{\mathrm{T}}$, X87161; Sphingomonas sanguis IFO $13937^{\mathrm{T}}$, D13937; Sphingomonas parapaucimobilis IFO $15100^{\mathrm{T}}$, X72721; Porphyrobacter neustonensis ACM 2844 ${ }^{\mathrm{T}}$, M96745; Rhizomonas suberifaciens IFO 15211 ${ }^{\mathrm{T}}$, D13737; Sphingomonas aromaticivorans SMCC F1T99 ${ }^{\mathrm{T}}$, U20756; Sphingomonas stygia SMCC B0712 ${ }^{\mathrm{T}}$, U20775; Sphingomonas subterranea SMCC B0478 ${ }^{\mathrm{T}}$, U20773.

\section{RESULTS AND DISCUSSION}

Morphological and physiological differences among Erythromicrobium species. The main phenotypic differences of the five Erythromicrobium species are presented in Table 1.

All species synthesize a large amount of carotenoid pigments, which determine the color of the organism. E. ramosum was shown to produce at least 10 kinds of carotenoids (38). The two main carotenoids, the orange erythroxanthin sulfate and the red bacteriorubixanthinal, are very polar. According to the in vivo absorption spectra of "E. ezovicum," "E. hydrolyticum," and $E$. ramosum, the major carotenoid peaks at 466 and 478 $\mathrm{nm}$ indicate similar carotenoid compositions in these species, apparent as a similar color of liquid cultures (intensely redorange). The carotenoid compositions, or at least the major pigments, of " $E$. sibiricum" (absorption at 424, 450, and 474 $\mathrm{nm}$ ) and "E. ursincola" (absorption at 430, 458, and $485 \mathrm{~nm}$ ) are different from those determined for the three above-mentioned species and different from each other, consistent with the colors of liquid cultures (yellow-orange for "E. sibiricum" and orange-brown for "E. ursincola") (Table 1).

The cell morphologies and the types of cell division are also significantly different and distinguish "E. sibiricum" and " $E$. ursincola" from the other three species and from each other. E. ramosum, "E. ezovicum," and " $E$. hydrolyticum" are very long rods and produce characteristic thread-like cells, dividing by symmetric or asymmetric constriction. For E. ramosum and "E. hydrolyticum," ternary fission and branching were demonstrated $(33,37)$.

"E. ursincola" cells are ovoid, and budding or asymmetric division can be used for reproduction (Fig. 1). Thus, budding is a distinctive phenotypic property of " $E$. ursincola."

"E. sibiricum" has long, thin cells producing long chains 

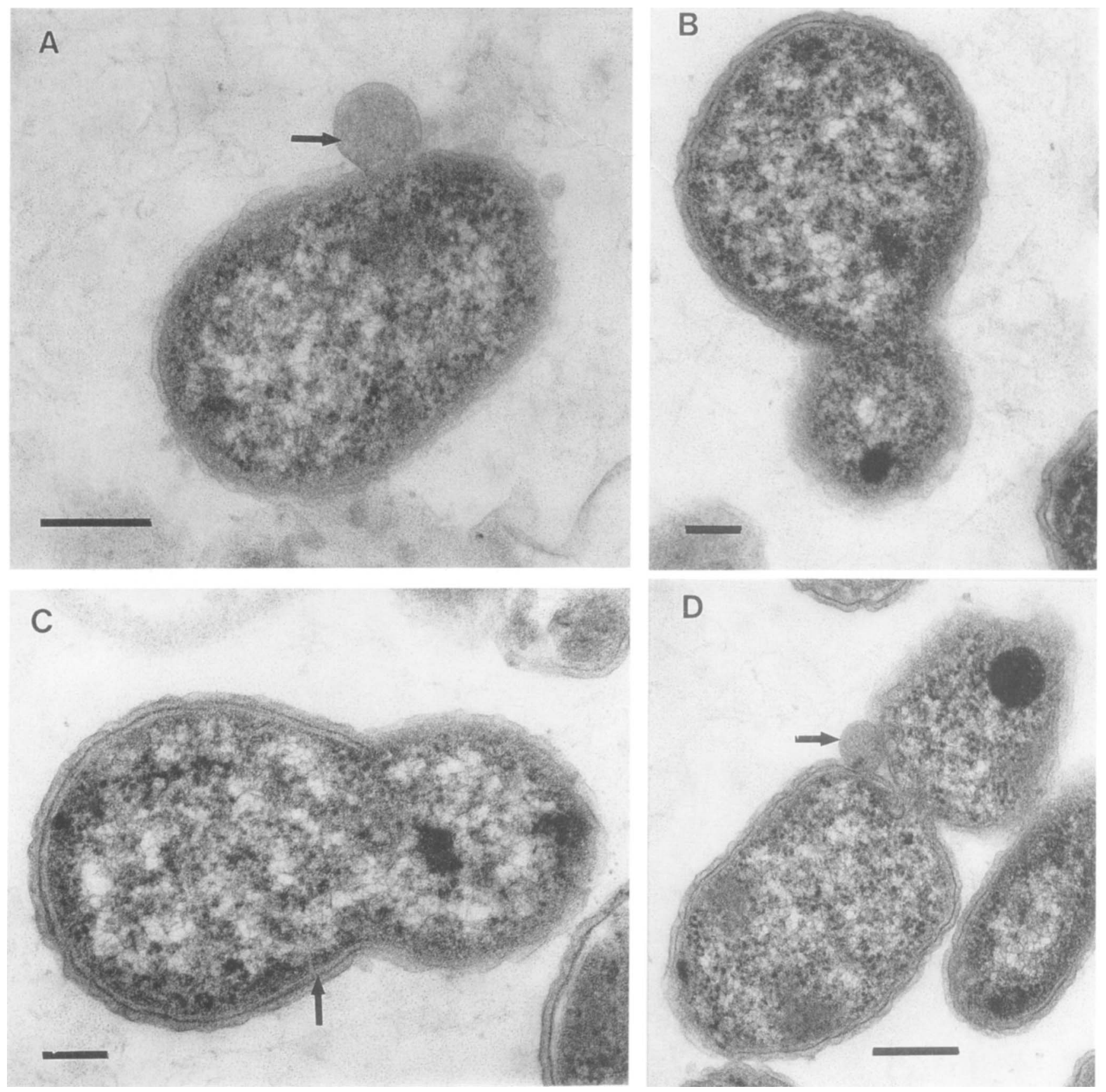

FIG. 1. Electron micrograph of "E. ursincola" thin-sectioned cells, showing different stages of bud formation. (A) Initiation of budding. (B) Young bud. (C) Older bud. The cell wall is structured and present in the mother cell only (arrow). (D) The daughter cell is not yet separated, and a new bud initiation point can already be seen (arrow). Bars, $200 \mathrm{~nm}$ (A and D) and $100 \mathrm{~nm}(\mathrm{~B}$ and C).

(sometimes up to 10 cells) and reproduces by binary division. Budding or branching has not been observed in "E. sibiricum."

The organic compounds utilized as carbon sources and the antibiotic sensitivities of the five species studied in this work are summarized in Table 1.

Characteristics of the photosynthetic apparatus and electron carriers. Several photoheterotrophic bacteria have the capability to grow by either photosynthesis or respiration. These two electron transfer systems share some carriers, such as soluble cyt's, quinone molecules, and cyt $b c_{1}$ complexes. In addition, the photosynthetic apparatus in all purple bacteria contains the photochemical $\mathrm{RC}$ center and one or more types of light-harvesting complex (5). The structure and amino acid composition of these components are evolutionarily highly conserved and can be used as a taxonomic marker in bacterial classification $(14,17)$.

As reported for E. ramosum $(38,39)$, membranes of " $E$. hydrolyticum" and "E. ezovicum" also contain two types of antenna complexes, LHI and LHII. We have isolated and purified LHII and RC-LHI particles by detergent treatment of membranes and sucrose gradient fractionation (Fig. 2; Table 2). 


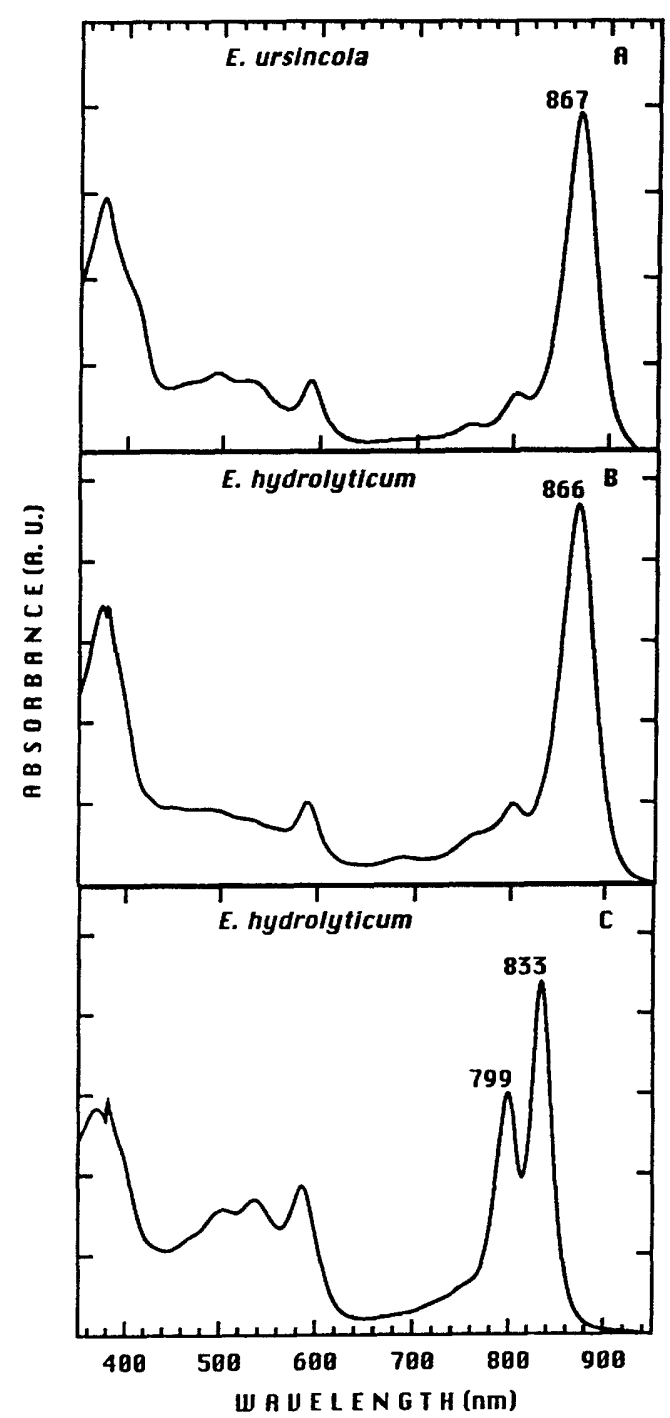

FIG. 2. Room temperature absorption spectra of RC-LHI complexes isolated from "E. ursincola" (A) and "E. hydrolyticum" (B), and absorption spectrum of LHII complexes purified from " $E$. hydrolyticum" $(\mathrm{C})$.

The isolated LHII complexes from "E. hydrolyticum" and "E. ezovicum," as well as those from $E$. ramosum, showed Bchl absorption maxima at 798 to 800 and 832 to $833 \mathrm{~nm}$, indicating the presence of new types of LHII (Table 2). The long-wave- length band of LHII at 832 to $833 \mathrm{~nm}$ is about $20 \mathrm{~nm}$ less than that usually observed in purple bacteria. LHII complexes absorbing at similar wavelengths were shown for Rhodopseudomonas acidophila and Rhodopseudomonas palustris cells grown under special temperature or light intensity conditions $(1,6$, $10,25)$. These peculiar spectral features found for the antenna complexes of aerobic photosynthetic bacteria indicate an unusual protein environment for Bchl $a$ molecules, which is supported by preliminary Raman spectroscopy data (9).

The species "E. sibiricum" and "E. ursincola" synthesize only the LHI type of antenna, which absorbs maximally at $867 \mathrm{~nm}$ (Table 2; Fig. 2).

The analysis of the light-induced difference spectra in the presence of oxygen in whole cells of Erythromicrobium representatives, as well as redox titrations and gel electrophoresis of their soluble, membrane, and LHI-RC purified fractions (41), led us to distinguish two clearly different groups on the basis of their behaviors and cyt composition (Table 2).

The very fast cyt photooxidation observed after flash excitation in the cells of "E. ursincola" and "E. sibiricum" (41) indicates that the immediate electron donor to the RC in these species is an RC-bound cyt $c$ of 44.0 and $40.0 \mathrm{kDa}$ in " $E$. sibiricum" and "E. ursincola," respectively (Table 2 ). The species E. ramosum, "E. hydrolyticum," and "E. ezovicum" do not possess an RC-bound cyt $c$, and the photooxidized special pair $\left(\mathrm{P}^{+}\right)$of the $\mathrm{RC}$ is directly reduced by a soluble cyt $c(41)$.

A detailed cyt composition analysis of the soluble and membrane fractions of Erythromicrobium representatives shows that despite the existence of RC-bound cyt $c$ in "E. sibiricum" and "E. ursincola," their total cyt $c$ compositions are significantly different (Table 2). "E. ursincola" contains a more complex soluble and membrane-bound cyt $c$ population, whereas the "E. sibiricum" soluble (one cyt $c$ of $14.0 \mathrm{kDa}$ ) and membrane (two cyt $c$ 's, including the RC-bound one) fractions have fewer types of cyt. Interestingly, "E. ursincola" contains an unusually small soluble cyt $c$ of $6.5 \mathrm{kDa}$. Such a small cyt $c$ is rarely found in bacteria and is present in Hydrogenobacter thermophilus (cyt $c_{550}$ of $6.0 \mathrm{kDa}$ ), Methylomonas strain A4 (cyt $c_{554}$ of $4.0 \mathrm{kDa}$ ) (29), and the obligately aerobic photosynthetic bacteria Roseococcus thiosulfatophilus RB3 (cyt $c_{549}$ and cyt $c_{552}$ of 6.5 and 4.0 $\mathrm{kDa}$, respectively) (41).

The difference in quinone composition between " $E$. sibiricum" and "E. ursincola" has been described elsewhere (11). "E. ursincola" seems to lack quinone $\mathrm{Q}_{9}$ and contains only quinone $\mathrm{Q}_{10}$. In "E. sibiricum" both quinones $\mathrm{Q}_{9}$ and $\mathrm{Q}_{10}$ are present (Table 2).

From the taxonomic point of view, the compilations of properties described in the above paragraph are useful. On the one hand, in the genus Erythromicrobium, the photosynthetic ap-

TABLE 2. Comparative data on photosynthetic apparatus organization and electron transfer carriers ${ }^{a}$

\begin{tabular}{|c|c|c|c|c|c|c|c|c|}
\hline \multirow{2}{*}{ Spccies } & \multirow{2}{*}{$\mathrm{RC}$} & \multicolumn{2}{|c|}{$\begin{array}{l}\text { Absorption } \\
\text { peaks (nm) }\end{array}$} & \multicolumn{3}{|c|}{ cyt $c$} & \multicolumn{2}{|c|}{$\begin{array}{c}\text { Ubiquinone } \mathrm{e}^{b} \\
(\mathrm{mmol} / \mathrm{g} \text { of dry cells })\end{array}$} \\
\hline & & LHI & LHII & $\begin{array}{l}\text { RC bound } \\
(\mathrm{kDa})\end{array}$ & $\begin{array}{c}\text { Soluble } \\
\text { (no. }[\mathrm{kDa}] \text { ) }\end{array}$ & $\begin{array}{l}\text { Membrane bound } \\
\text { (no. }[\mathrm{kDa}])\end{array}$ & $\mathrm{Q}_{9}$ & $\mathrm{Q}_{10}$ \\
\hline "E. sibiricum" & + & 867 & Absent & 44.0 & $1(14.0)$ & $2(30.0,44.0)$ & 0.06 & 0.71 \\
\hline "E. ursincola" & + & 867 & Absent & 40.0 & $3(6.5,9.0,14.0)$ & $4(14.3,21.0,24.0,40.0)$ & ND & 0.11 \\
\hline E. ramosum & + & 868 & 798,832 & Absent & $2(8.0,14.3)$ & $3(8.0,26.0,30.0)$ & 0.09 & $0.19^{\mathrm{M}}$ \\
\hline "E. ezovicum" & + & 868 & 800,832 & Absent & $2(8.0,14.3)$ & $2(30.0,34.0)$ & 0.02 & 0.3 \\
\hline "E. hydrolyticum" & + & 866 & 799,833 & Absent & $1(14.3)$ & $2(21.0,30.0)$ & 0.02 & $0.01^{\mathrm{M}}$ \\
\hline
\end{tabular}

${ }^{a}$ Species were cultivated in the dark under aerobic conditions. + , present.

${ }^{b}$ Data are cited from reference 11 . ND, not detected. A superscript " $\mathrm{M}$ " appended to a value means that in addition to the common ubiquinone $\mathrm{Q}_{10}$, its methylated form was revealed. 
parati of "E. sibiricum" and "E. ursincola" are composed of RC with a bound tetraheme cyt $c$ and only one type of lightharvesting antenna, LHI. On the other hand, E. ramosum, "E. hydrolyticum," and "E. ezovicum" do not possess an RCbound cyt $c$, and a soluble cyt $c_{2}$ seems to complete the cyclic electron transfer in the photosynthetic pathways of these three species, which contain an unusual B798-832 LHII complex. These differences in photosynthetic apparatus organization and composition of electron carriers are consistent with the heterogeneity of the genus Erythromicrobium deduced from DNA-DNA hybridization data (36) and 5S rRNA sequence comparisons (28), supporting a separation of " $E$. ursincola" and "E. sibiricum" from the genus Erythromicrobium.

Phylogenetic analysis. Nearly complete 16S rDNA sequences were determined for the strains " $E$. ursincola" and "E. sibiricum." The sequences were aligned with homologous sequences of members of the $\alpha$ subclass of Proteobacteria, and the phylogenetic positions were determined. All nonambiguous positions between positions 49 and 1376 ( $E$. coli numbering; the actual number of bases was always higher than 1,000 ) (2) were included in the phylogenetic analysis. The sequences of a subset of 20 strains of Erythromicrobium, Erythrobacter, Porphyrobacter, Blastomonas, and related taxa (i.e., members of Sphingomonas, Rhizomonas, Zymomonas, and some misclassified strains) $(16,18)$ were used to generate a matrix of similarity.

With respect to the phylogenetic positions of the two nonvalid strains of Erythromicrobium, all algorithms used in this study $(3,7)$ invited the same conclusions: these two strains do not cluster with $E$. ramosum and relatives, but they form two separate sublines on the evolutionary tree of Sphingomonas species with a binary similarity value of $92.5 \%$. The branching point of "E. ursincola" is between Sphingomonas subcluster 2 and subclusters 1 and 3 (Fig. 3), while that of "E. sibiricum" is between subcluster 4 and subclusters 1,2 , and 3 . The lack of high bootstrap values found for the branching of these subclusters indicates low statistical significance of the order of the several subclusters, which has been previously reported (26). The two species investigated here show lower than $96 \% 16 \mathrm{~S}$ rDNA identity to Sphingomonas reference organisms. While "E. ursincola" shows the highest sequence identity to $B$. natatoria $(99.8 \%)$, " $E$. sibiricum" stands phylogenetically isolated, showing less than $93.5 \%$ sequence identity with any of the reference organisms included in this study. The dendrogram (Fig. 3) includes the phylogenetic positions of some other obligately aerobic Bchl $a$-containing bacteria $(R$. thiosulfatophilus and $R$. denitrificans) of the $\alpha$ subclass of the Proteobacteria, the positions of which have been shown previously (40).

This phylogenetic analysis of the $16 \mathrm{~S}$ rDNA of the two nonvalidly described species of Erythromicrobium clearly reveals that they cannot be considered members of this genus. However, it does not follow from their affiliation with members of the genus Sphingomonas that they should be considered novel species of Sphingomonas. The phylogenetic heterogeneity of Sphingomonas has been noted before, as several Sphingomonas-unlike organisms, such as Rhizomonas suberifaciens, B. natatoria, and Zymomonas mobilis have been found to branch between or close to the four recognized Sphingomonas species subgroups $(18,26)$. The branching of the two Bchl $a$-containing strains of Erythromicrobium within the Sphingomonas group adds a novel biochemical trait which has not been detected before in members of this group.

"E. sibiricum" forms a single subline of descent, whereas "E. ursincola" clusters with $B$. natatoria (13). In our opinion, the significant phenotypic and physiological differences between " $E$. ursincola" and $B$. natatoria preclude their assign-

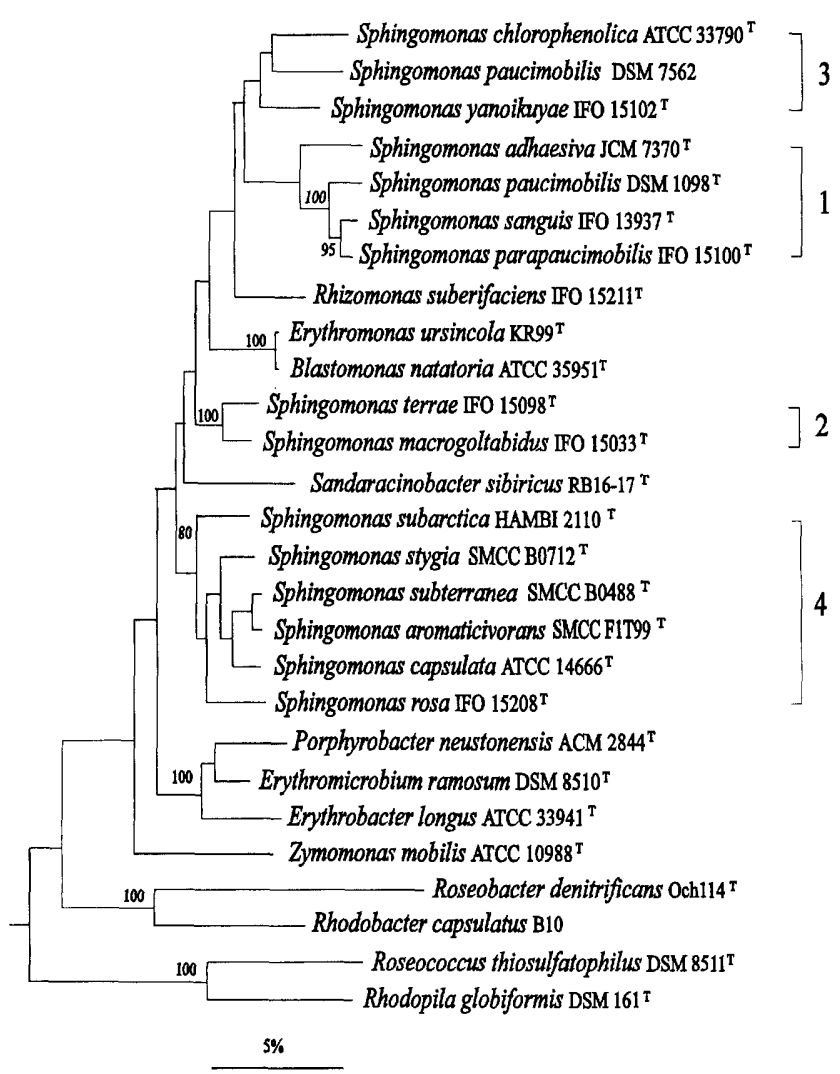

FIG. 3. $16 \mathrm{~S}$ rDNA dendrogram of relatedness showing the phylogenetic positions of Erythromonas ursincola and Sandaracinobacter sibiricus on the evolutionary tree of members of the genus Sphingomonas and related taxa. The dendrogram was generated by the algorithm of De Soete (3) on the basis of the dissimilarity values. The sequence of Agrobacterium tumefaciens was used to root the dendrogram. Numbers refer to bootstrap values, of which only those above $80 \%$ are shown. The length corresponding to $5 \%$ inferred sequence divergence is indicated at the bottom.

ment to the same genus. $B$. natatoria is a nonphotosynthetic species containing carotenoid pigments and lacking Bchl, whereas " $E$. ursincola" is physiologically related to obligately aerobic anoxygenic photosynthetic bacteria producing carotenoids and Bchl $a$. "E. ursincola" contains Bchl $a$ incorporated into photochemically active RC and light-harvesting complexes, and it contains specific electron transfer carriers of a cyclic photosynthetic pathway (such as cyt $c$ bound to the RC, soluble cyt $c_{2}$, the $\mathrm{RC} \mathrm{Q}_{\mathrm{A}}$ primary electron acceptor, and the "special pair" $P$ of the RC). High 16S rDNA sequence similarity between these two species indicates a close phylogenetic relationship and suggests that they have a common ancestor; conceivably one is an evolutionary progenitor of the other. However, due to the existence of significant physiological differences (photosynthesis is a restricted mode of energy generation), they should not be designated members of the same genus for taxonomic purposes.

Taken together, the results described in this paper require elevation of "E. ursincola" and "E. sibiricum" to type species of two new genera of the $\alpha$ subclass of the Proteobacteria: Erythromonas ursincola gen. nov., sp. nov., and Sandaracinobacter sibiricus gen. nov., sp. nov. Thus, the genus Erythromicrobium is at present composed of the three species E. ramosum (type species), "E. hydrolyticum," and "E. ezovicum." Descriptions of the three species of the genus Erythromicrobium have been given in previous publications $(33,40)$. 
Summary descriptions of the two new genera are given below.

Description of Sandaracinobacter gen. nov. Sandaracinobacter (San.da.ra.ci.no.bac'ter. Gr. adj. sandaracinos, orange-colored; Gr. n. bacter, rod; M.L. masc. n. sandaracinobacter, orange-colored rod).

Cells are thin, long rods, forming chains. Motile by means of subpolar flagella, gram negative. Divide by binary division. Cultures are intensely yellow-orange because of carotenoid pigments.

Contain Bchl a. Photosynthetic apparatus consists of RC and LHI. RC contains a tightly bound tetraheme cyt $c$.

Aerobic chemoorganotrophic and facultative photoheterotrophic metabolisms. No growth occurs anaerobically in the light. Ribulose-bisphosphate carboxylase is not detected. No fermentation or denitrification activities detected.

DNA base composition is $68.5 \mathrm{~mol} \% \mathrm{G}+\mathrm{C}$ (by thermal denaturation).

The habitat is freshwater. Not halophilic.

Member of the $\alpha-4$ subclass of the Proteobacteria.

The type species is Sandaracinobacter sibiricus (formerly "E. sibiricum") (37).

Description of Sandaracinobacter sibiricus sp. nov. Sandaracinobacter sibiricus (si.bi'ri.cus. L. adj. sibiricus, isolated in Siberia).

Gram-negative, yellow-orange-pigmented, thin, long rods, 0.3 to 0.5 by 1.5 to $2.5 \mu \mathrm{m}$ or more. Motile by means of subpolar flagella (up to three).

Cells contain Bchl $a$ and carotenoid pigments. Carotenoids give main absorption peaks at 424,450 , and $474 \mathrm{~nm}$ in vivo. The cytoplasmic membranes contain an RC and LHI with absorption peaks at 750,799 , and $857 \mathrm{~nm}$ for RC and $867 \mathrm{~nm}$ for LHI. Tetraheme cyt $c$ of $44.0 \mathrm{kDa}$ is tightly bound to RC and is its immediate electron donor. Additionally contain soluble cyt $c$ of $14.0 \mathrm{kDa}$ and membrane-bound cyt $c$ of $30.0 \mathrm{kDa}$ (cyt of $b c_{1}$ complex). Contains quinones $\mathrm{Q}_{9}$ and $\mathrm{Q}_{10}$. Menaquinone is not found (11).

Aerobic chemoorganotroph and facultative photoheterotroph. The best growth substrates are butyrate, sucrose, casein hydrolysate, and yeast extract. Good growth is observed on acetate and maltose; weak growth on media containing glucose, fructose, pyruvate, propionate, or glycerol. No utilization of ribose, sorbitol, benzoate, fumarate, formate, succinate, citrate, malate, methanol, or ethanol.

Optimal temperature for growth is 25 to $30^{\circ} \mathrm{C}$. Freshwater bacteria; salinity above $1.0 \% \mathrm{NaCl} /$ liter of media strongly inhibits growth. The $\mathrm{pH}$ optimum is 7.5 to 8.5 . The bacteria exhibit oxidase activity and lack catalase activity. Hydrolyze Tween 60 and do not hydrolyze gelatin or starch.

Resistant to chloramphenicol, fusidic acid, streptomycin, amikacin, bacitracin, kanamycin, neomycin, and novobiocin. Sensitive to penicillin, ampicillin, tetracycline, polymyxin B, erythromycin, nalidixic acid, lincomycin, mycostatin, aureomycin, and vancomycin.

Demonstrate a high level of resistance to tellurite. Tellurite resistance depends on medium composition, particularly on organic carbon source. The highest tellurite concentration tolerated is $1,200 \mu \mathrm{g} / \mathrm{ml}$ in media containing acetate or yeast extract as a sole organic source. Tellurite can be reduced and transformed into metallic tellurium accumulated inside cells (42).

Storage compounds: polyphosphates, polysaccharide, and poly- $\beta$-hydroxybutyrate.

The DNA G $+C$ content is $68.5 \mathrm{~mol} \%$.

Habitat: freshwater algobacterial mat near hydrothermal sulfide-containing vents along the river bottom.
The type strain is RB16-17.

Description of Erythromonas gen. nov. Erythromonas (E.ry. thro.mo'nas. Gr. adj. erythros, red; Gr. n. monas, a unit, monad; M.L. fem. n. Erythromonas, red monad).

Gram negative, ovoid cells, motile by means of a polar flagellum. Do not form chains. Reproduce by budding or asymmetric division.

The cells are orange-brown due to carotenoid pigments. Contain Bchl $a$. Photosynthetic apparatus is organized in RC with tightly bound tetraheme cyt $c$ and LHI.

Obligately aerobic, chemoorganotrophic (respiratory metabolism), and facultatively photoheterotrophic. No growth occurs under anaerobic conditions in the light. $\mathrm{NaCl}$ is not required for growth.

The DNA $\mathrm{G}+\mathrm{C}$ content is $65.4 \mathrm{~mol} \%$ (as determined by thermal denaturation).

Phylogenetically related to members of the $\alpha-4$ subclass of the Proteobacteria.

The type species is Erythromonas ursincola (formerly "Enythromicrobium ursincola" [37]).

Description of Erythromonas ursincola sp. nov. Erythromonas ursincola (ur.sin'co.la. M.L. adj. ursincola, neighbor or compatriot of bears).

The cells are gram negative and ovoid, 0.8 to 1.0 by 1.3 to 2.6 $\mu \mathrm{m}$. Long chains are not formed. Reproduce by budding or asymmetric division. Cells motile by means of a unique polar flagellum.

The cells contain Bchl $a$ and carotenoid pigments. Carotenoids give three main absorption peaks at 430,458 , and $485 \mathrm{~nm}$ in vivo, and in combination with Bchl $a$ determine the colors of orange in young cultures and dark orange-brown in older liquid or young agar cultures. Bchl $a$ is present in membranebound protein-pigment complexes, consisting of the RC with absorption peaks at 751,801 , and $853 \mathrm{~nm}$ and core LHI absorbing at $867 \mathrm{~nm}$. RC contains tightly bound tetraheme cyt $c$ with molecular size of $40.0 \mathrm{kDa}$. Total cyt $c$ of cells growing in the dark is very abundant and represented by soluble cyt $c$ 's of $6.5,9.0$, and $14.0 \mathrm{kDa}$ and by membrane-bound cyt $c$ 's of 14.3 , 21.0 , and $24.0 \mathrm{kDa}$. In cells growing in the dark, only quinone $\mathrm{Q}_{10}$ was found (11).

Aerobic, chemoorganotroph, facultative photoorganoheterotroph. The best growth is on media containing glucose, fructose, sucrose, maltose, acetate, glutamate, propionate, casein hydrolysate, or yeast extract. Good growth on pyruvate, butyrate, malate, or succinate. Poor growth on media supplemented with arabinose, citrate, lactate, glycerol, or mannitol. No growth detected in media containing ribose, formate, benzoate, tartrate, methanol, ethanol, or glycolate.

The tricarboxylic acid cycle, and glyoxylate shunt during growth on an acetate-containing medium, is present.

The key enzyme of Calvin cycle, ribulose-bisphosphate carboxylase, is not found. No anaerobic growth in the light, fermentation, or denitrification is found.

Optimal growth temperature is 25 to $30^{\circ} \mathrm{C}$. Freshwater organism, does not require $\mathrm{NaCl}$ for growth. Optimum $\mathrm{pH}$ is 7.0 to 8.0. Yeast extract and vitamin $B_{12}$ satisfy the requirement for growth factors. Oxidase and catalase positive. Tween 80 is hydrolyzed. Lipase activity of $64.9 \mathrm{U} / \mathrm{g}$ of biomass. Starch and gelatin are not hydrolyzed.

Sensitive to tetracycline, polymyxin B, amikacin, gentamicin, neomycin, aureomycin, vancomycin, novobiocin, chloramphenicol, and fusidic acid. Resistant to penicillin, ampicillin, streptomycin, erythromycin, nalidixic acid, lincomycin, mycostatin, bacitracin, and kanamycin.

Very resistant to tellurite. Can grow in the presence of tellurite concentrations up to $2,700 \mu \mathrm{g} / \mathrm{ml}$ in acetate-containing 
minimal medium. Resistance to tellurite depends on the presence of an organic carbon source in the medium. Tellurite can be reduced and transformed into metallic tellurium accumulated as metal crystals in cell cytoplasm (42).

Storage compounds: polyphosphates.

The DNA GC content is $65.4 \mathrm{~mol} \%$ (by thermal denaturation).

Habitat: freshwater cyanobacterial mat developing in the thermal springs at $\mathrm{pH} 6.7$ to 7.0 and at temperatures from 34 to $40^{\circ} \mathrm{C}$ on Kamchatka Island (Russia).

Type strain is KR-99.

\section{ACKNOWLEDGMENTS}

This work was supported by grants from NSERC (Canada) and CEA (France).

We thank J. Jappé for assistance in electronic microscopy.

\section{REFERENCES}

1. Bissig, I., R. V. Wagner-Huber, B. A. Brunisholz, and H. Zuber. 1990. Multiple antenna complex in various purple photosynthetic bacteria, p. 199210. In G. Drews and E. A. Dawes (ed.), Molecular biology of membranebound complexes in phototrophic bacteria. Plenum Press, New York, N.Y.

2. Brosius, J., M. L. Palmer, J. P. Kennedy, and H. P. Noller. 1978. Complete nucleotide sequence of a $16 \mathrm{~S}$ ribosomal RNA gene from Escherichia coli. Proc. Natl. Acad. Sci. USA 75:4801-4805.

3. De Soete, G. 1983. A least squares algorithm for fitting additive trees to proximity data. Psychometrika 48:621-626.

4. Drews, G. 1983. Mikrobiologisches Praktikum, p. 11. Springer, Berlin, Germany.

5. Drews, G. 1989. Energy transduction in phototrophic bacteria, p. 461-480. In H. G. Schlegel and B. Bowien (ed.), Biology of autotrophic bacteria. Science and Technology Publishers, Madison, Wis.

6. Evans, M. B., A. M. Hawthornthwaite, and R. J. Cogdell. 1990. Isolation and characterisation of the different B800-850 light-harvesting complexes from low- and high-light grown cells of Rhodopseudomonas palustris, strain 2.1.6. Biochim. Biophys. Acta 1016:71-76.

7. Felsenstein, J. 1993. Phylip (phylogeny interference package), version $3.5 \mathrm{c}$ J. Felsenstein, University of Washington, Seattle.

8. Fuerst, J. A., J. A. Hawkins, A. Holmes, L. I. Sly, C. J. Moore, and E. Stackebrandt. 1993. Porphyrobacter neustonensis gen. nov., sp. nov., an aerobic bacteriochlorophyll-synthesizing budding bacterium from freshwater. Int. J. Syst. Bacteriol. 43:125-134.

9. Gall, A., V. Yurkov, R. J. Cogdell, A. Vermeglio, and B. Robert. 1995. The pigment-protein interactions of some unusual light-harvesting antennae: a Raman study, p. 251-254. In P. Mathis (ed.), Photosynthesis: from light to biosphere. Kluwer Academic Publishers, Dordrecht, The Netherlands.

10. Gardiner, A. T., R. C. MacKenzie, S. J. Barret, K. Kaiser, and R. J. Cogdell. 1992. The genus for the peripheral antenna complex apoproteins from Rhodopseudomonas acidophila 7050 form a multigene family, p. 77-80. In N Murata (ed.), Research in photosynthesis. Kluwer Academic Publishers, Dordrecht, The Netherlands.

11. Gogotov, I. N., and V. M. Gorlenko. 1995. Influence of cultivation conditions on the composition of quinones in purple bacteria and freshwater Erythrobacteria. Microbiology (New York) 64:654-656.

12. Harashima, K., K. Kawazoe, I. Yoshida, and H. Kamata. 1987. Light-stimulated aerobic growth of Erythrobacter species OCh 114. Plant Cell Physiol. 28:365-374.

13. Hugenholtz, P., E. Stackebrandt, and J. A. Fuerst. 1994. A phylogenetic analysis of the genus Blastobacter with a view to its future reclassification. Syst. Appl. Microbiol. 17:51-57.

14. Jones, D., and N. R. Krieg. 1984. Serology and chemotaxonomy, p. 15-18. In N. R. Krieg and J. G. Holt (ed.), Bergey's manual of systematic bacteriology, vol. 1. Williams and Wilkins, Baltimore, Md.

15. Jukes, T. H., and C. R. Cantor. 1969. Evolution of protein molecules, p. 21-132. In H. N. Munro (ed.), Mammalian protein metabolism. Academic Press, New York, N.Y.

16. Maidak, B. L., N. Larsen, M. J. McCaughey, R. Overbeek, G. J. Olsen, K. Fogel, J. Blandy, and C. R. Woese. 1994. The Ribosomal Database Project. Nucleic Acids Res. 22:3483-3487.

17. Nagashima, K. V. P., A. Hiraishi, K. Shimada, and K. Matsura. 1994 Phylogenetic analysis of photosynthetic reaction centers of purple bacteria, abstr. 58A, p. 58. In Abstracts of the VIIIth International Symposium on Phototrophic Prokaryotes. Tipolitografia Grafica Vadese, Di Sant' Agelo in Vado, Italy

18. Nohynek, L. J., E.-L. Nurmiaho-Lassila, E. L. Suhonen, H.-J. Busse, M. Mohammadi, J. Hantula, F. Rainey, and M. S. Salkinoja-Salonen. 1996 Description of chlorophenol-degrading Pseudomonas sp. strains $\mathrm{KF}^{\mathrm{T}}$, KF3, and NKF1 as a new species of the genus Sphingomonas, Sphingomonas subarctica sp. nov. Int. J. Syst. Bacteriol. 46:1042-1055.

19. Rainey, F. A., M. Dorsch, H. W. Morgan, and E. Stackebrandt. 1992.16S rDNA analysis of Spirochaeta thermophila: its phylogenetic position and implications for the systematics of the order Spirochaetales. Syst. Appl. Microbiol. 15:197-202.

20. Saitou, N., and M. Nei. 1987. The neighbor-joining method, a new method for reconstructing phylogenetic trees. Mol. Biol. Evol. 4:406-425.

21. Shiba, T. 1991. Roseobacter litoralis gen. nov., sp. nov., and Roseobacter denitrificans sp. nov., aerobic pink-pigmented bacteria which contain bacteriochlorophyll a. Syst. Appl. Microbiol. 14:140-145.

22. Shiba, T., and U. Simidu. 1982. Erythrobacter longus gen. nov., sp. nov., an aerobic bacterium which contains bacteriochlorophyll $a$. Int. J. Syst. Bacteriol. 32:211-217.

23. Shiba, T., U. Simidu, and N. Taga. 1979. Distribution of aerobic bacteria which contain bacteriochlorophyll $a$. Appl. Environ. Microbiol. 38:43-45.

24. Shiba, T., Y. Shioi, K. I. Takamiya, D. C. Sutton, and C. R. Wilkinson. 1991. Distribution and physiology of aerobic bacteria containing bacteriochlorophyll $a$ on the East and West coasts of Australia. Appl. Environ. Microbiol. 57:295-300.

25. Tadros, M. H., E. Katsiou, M. Hoon, N. Yurkova, and D. P. Ramji. 1993. Cloning of a new antenna gene cluster and expression analysis of the antenna gene family of Rhodopseudomonas palustris. Eur. J. Biochem. 217:867-875.

26. Takeuchi, M., H. Sawada, H. Oyaizu, and A. Yokota. 1994. Phylogenetic evidence for Sphingomonas and Rhizomonas as nonphotosynthetic members of the $\alpha-4$ subclass of the Proteobacteria. Int. J. Syst. Bacteriol. 44:308-314.

27. Thomas, P. E., D. Ryan, and W. Lewin. 1976. An improved staining procedure for the detection of the peroxidase activity of cytochrome P-450 on sodium dodecyl sulfate polyacrylamide gels. Anal. Biochem. 75:168-176.

28. Turova, T. P., M. V. Burkal'tseva, E. S. Bulygina, and V. M. Gorlenko. 1995. Phylogenetic position of freshwater Erythrobacteria studied by $5 \mathrm{~S}$ rRNA analysis. Microbiology (New York) 64:662-666.

29. Yamanaka, T. 1992. Group $c$ cytochromes, p. 91-168. In T. Yamanaka (ed.), The biochemistry of bacterial cytochromes. Japan Scientific Societies Press. Tokyo.

30. Yurkov, V. 1990. Biology of freshwater aerobic bacteria containing bacteriochlorophyll a. Ph.D. thesis. Academy of Sciences, Moscow, Russia. (In Russian.)

31. Yurkov, V., and V. M. Gorlenko. 1990. Enythrobacter sibiricus sp. nov., a new freshwater aerobic bacterial species containing bacteriochlorophyll $a$. Microbiology (New York) 59:85-89.

32. Yurkov, V., and V. M. Gorlenko. 1992. A new genus of freshwater aerobic, bacteriochlorophyll $a$-containing bacteria, Roseococcus gen. nov. Microbiology (New York) 60:628-632.

33. Yurkov, V., and V. M. Gorlenko. 1993. New species of aerobic bacteria from the genus Erythromicrobium containing bacteriochlorophyll $a$. Microbiology (New York) 61:163-168.

34. Yurkov, V., and H. van Gemerden. 1993. Impact of light/dark regime on growth rate, biomass formation and bacteriochlorophyll synthesis in Erythromicrobium hydrolyticum. Arch. Microbiol. 159:84-89.

35. Yurkov, V., and H. van Gemerden, 1993. Abundance and salt tolerance of obligately aerobic, phototrophic bacteria in a microbial mat. Neth. J. Sea Res. 31:57-62.

36. Yurkov, V., A. M. Lysenko, and V. M. Gorlenko. 1991. Hybridization analysis of the classification of bacteriochlorophyll $a$-containing freshwater aerobic bacteria. Microbiology (New York) 60:362-366.

37. Yurkov, V., V. M. Gorlenko, and E. I. Kompantseva. 1992. A new type of freshwater aerobic orange-coloured bacterium, Ervthromicrobium gen. nov. containing bacteriochlorophyll $a$. Microbiology (New York) 61:169-172

38. Yurkov, V., N. Gad'on, and G. Drews. 1993. The major part of polar carotenoids of the aerobic bacteria Roseococcus thiosulfatophilus RB3 and Evth romicrobium ramosum E5 is not bound to the bacteriochlorophyll a complexes of the photosynthetic apparatus. Arch. Microbiol. 160:372-376.

39. Yurkov, V., N. Gad'on, A. Angerhofer, and G. Drews. 1994. Light-harvesting complexes of aerobic bacteriochlorophyll-containing bacteria Roseococcus thiosulfatophilus, RB3 and Erythromicrobium ramosum, E5 and the transfer of excitation energy from carotenoids to bacteriochlorophyll. Z. Naturforsch. Sect. C 49:579-586.

40. Yurkov, V., E. Stackebrandt, A. Holmes, J. A. Fuerst, P. Hugenholtz, J. Golecki, N. Gad'on, V. M. Gorlenko, E. I. Kompantseva, and G. Drews. 1994 Phylogenetic positions of novel aerobic, bacteriochlorophyll a-containing bacteria and description of Roseococcus thiosulfatophilus gen. nov., sp. nov. Erythromicrobium ramosum gen. nov., sp. nov., and Erythrobacter litoralis sp. nov. Int. J. Syst. Bacteriol. 44:427-434.

41. Yurkov, V., B. Schoepp, and A. Vermeglio. 1995. Electron transfer carriers in obligately aerobic photosynthetic bacteria from genera Roseococcus and Enythromicrobium, p. 543-546. In P. Mathis (ed.), Photosynthesis: from light to biosphere. Kluwer Academic Publishers, Dordrecht, The Netherlands.

42. Yurkov, V., J. Jappé, and A. Verméglio. 1996. Tellurite resistance and reduction by obligately aerobic photosynthetic bacteria. Appl. Environ. Microbiol. 62:4195-4198. 